\title{
Coeliac disease during the teenage period: The value of serial serum folate estimations
}

\author{
D. G. WEIR' ${ }^{1}$ AND D. O'B. HOURIHANE \\ From the Departments of Clinical Medicine and Pathology, Trinity College, Dublin
}

SUMMARY A group of teenage coeliac patients has been followed at three monthly intervals in the Outpatient Department to assess their progress and also to monitor their ability to maintain a gluten-free diet. After a follow-up period of four to six years a detailed reassessment was carried out in hospital on 10 patients, only five of whom had persevered with a gluten-free diet. The jejunal mucosal histology of those patients who did not persist with a gluten-free diet remained 'flat' although these patients appeared to have remitted clinically. Those subjects who did persist with a gluten-free regime had a normal or near normal mucosal histology. It was difficult on the basis of clinical, haematological, or biochemical criteria to separate the two groups. The best single assessment of whether these patients were maintaining a gluten-free diet was serial serum folate estimations. It is often extremely difficult to say whether teenage coeliac patients are keeping to their diet unless repeated jejunal biopsies are obtained, and this study suggests that serial serum folate estimations can act as a reasonable criterion of whether subjects are maintaining a gluten-free regime.

It is now apparent that the sensitivity of the jejunal mucosa to gluten in coeliac patients is not confined to the paediatric period but is probably present throughout life (Sheldon and Tempany, 1966; Mortimer, Stewart, Norman, and Booth, 1968; Sheldon, 1969). Accordingly it is in the best interest of these patients that they should remain on a glutenfree diet both from the point of view of their general health and because the 'flat' intestinal mucosa which results from a gluten challenge in these subjects is a premalignant lesion (Gough, Read, and Naish, 1962; Harris, Cooke, Thompson, and Waterhouse, 1966; Austad, Cornes, Gough, McCarthy, and Read, 1967; Brunt, Sircus, and MacLean, 1969). It is probable that withdrawing gluten from the diet on a permanent basis will protect them from the tendency to malignant change (Harris, Cooke, Thompson, and Waterhouse, 1967).

Gluten withdrawal, however, remains an extremely difficult therapeutic regime to maintain, particularly in teenage children and young adults. These patients on occasional or even prolonged dietary indulgence of gluten-containing foods often do not suffer any symptoms or show any clinical signs of gluten toxicity. Accordingly the clinician

${ }^{1}$ Requests for reprints should be sent to Professor D. G. Weir, Department of Gastroenterology, Sir Patrick Dun's Hospital, Dublin Received for publication 15 March 1974. requires a test which will allow him to assess if the coeliac patient is adhering to a diet which is free from gluten.

In this communication a group of young coeliac patients was followed prospectively to assess which of a group of routine biochemical and haematological blood tests was best suited to assess the clinical progress of the patient.

\section{Methods}

Twenty-three coeliac patients in their second decade, the majority of whom had previously been treated by paediatricians elsewhere, were investigated in hospital. At the time of this initial assessment none of the subjects was strictly maintaining a gluten-free diet; they commenced such a diet while in hospital. Fifteen of the patients were subsequently followed up at three monthly intervals in the Outpatient Department. After a prospective follow-up period of five to six years 10 subjects agreed to come into hospital for re-evaluation and the results from these 10 patients form the basis of this study.

The hospital inpatient investigations included the following parameters: height and weight, haemoglobin and blood indices, total serum proteins and serum albumin, serum calcium, phosphate and alkaline phosphatase, serum iron (Ferro test, 
Hyland), serum vitamin $B_{12}$ (Temperley and Collery, 1965), and serum folate (Temperley and Spray, 1966). The following tests of intestinal absorption were performed; d-xylose tolerance test (Chanarin and Bennett, 1962) and a five-day faecal fat collection (van de Kamer, Huinick, and Weyers, 1949). A jejunal biopsy was obtained using the Crosby capsule (Crosby and Kugler, 1957). A barium followthrough radiograph of the small intestine was obtained in each subject during the first admission only.

At the outpatient review particular emphasis was placed on whether the patients had or had not adhered to a gluten-free diet during the previous three months. Each subject was allocated to one of three groups on the basis of this interview: (a) complete adherence to the diet; $(b)$ minimal infringements of the diet; and (c) an inadequate attempt to maintain the diet. The allocation was made without prior knowledge of the laboratory reports obtained during the previous interview. The results of the dietary assessment using these criteria for the whole group are shown in figure 1. Fortuitously it was found that the patients fell into two rather than three groups, as five adhered to a gluten-free diet to an acceptable degree, the 'gluten-free diet' group, while five for a variety of personal reasons and against medical advice did not, the 'non-gluten-free diet' group.

Each patient was then weighed and measured and a blood sample was taken on a rota system which ensured that all of the following parameters were assessed at least once a year. These included a full blood count and indices, serum calcium, serum phosphate and alkaline phosphatase, serum iron, serum vitamin $\mathbf{B}_{12}$, serum folate, total proteins and serum albumin.

\section{Results}

\section{COMPARISON OF THE TWO GROUPS}

\section{Physical development}

The clinical features are shown in the table. The majority of the patients were complaining of some gastrointestinal symptoms when they were first reviewed. During the follow-up period immediately after their discharge from hospital on a gluten-free diet these patients were all symptom free. A feature of the study was that whether or not they adhered to the gluten-free diet they remained virtually symptom free throughout the period of review.

There was no appreciable difference between the two groups in regard to physical development

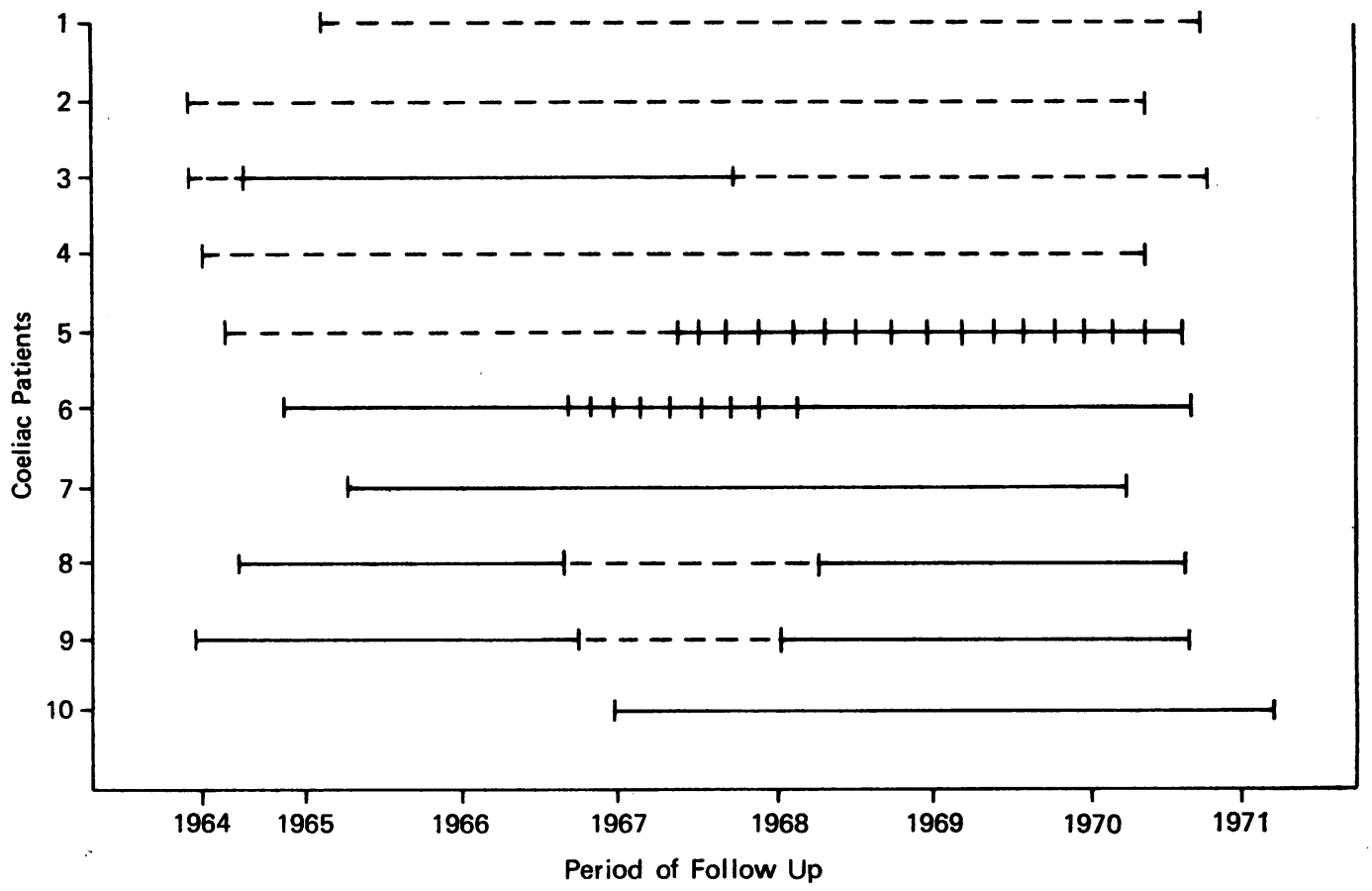

Fig 1 Period of time each subject stayed on a gluten-free diet (- - - group $A ; 1-|-|-\mid$ group B; group C). 


\begin{tabular}{|c|c|c|c|c|c|c|c|c|}
\hline \multirow{2}{*}{\multicolumn{2}{|c|}{ Patient }} & \multirow[t]{2}{*}{$\operatorname{Sex}$} & \multirow{2}{*}{$\begin{array}{l}\text { Age and Duration } \\
\text { of Observation } \\
\text { Period }\end{array}$} & \multirow{2}{*}{$\begin{array}{l}\text { Gluten- } \\
\text { free } \\
\text { Diet }\end{array}$} & \multicolumn{2}{|l|}{ Clinical Symptoms } & \multicolumn{2}{|c|}{ Growth during Observation Period } \\
\hline & & & & & $\begin{array}{l}\text { Original } \\
\text { Admission }\end{array}$ & Readmission & Height (in) & Weight (kg) \\
\hline 1 & M.L. & $\mathbf{F}$ & $\begin{array}{l}14 \\
20\end{array}$ & Yes & $\begin{array}{l}\text { Diarrhoea and } \\
\text { anorexia }\end{array}$ & Nil & $60-63$ & $36-49$ \\
\hline 2 & F.T. & $\mathbf{F}$ & $\begin{array}{l}12 \\
17\end{array}$ & Yes & $\begin{array}{l}\text { Diarrhoea, nausea, } \\
\text { abdominal pain }\end{array}$ & Nil & $54-63$ & 28-50 \\
\hline 3 & A.O'G. & $\mathbf{F}$ & $\begin{array}{l}18 \\
24\end{array}$ & Yes & Diarrhoea, ataxia & Nil & $58-60$ & $41-43$ \\
\hline 4 & A.M. & $\mathbf{F}$ & $\begin{array}{l}17 \\
23\end{array}$ & Yes & $\begin{array}{l}\text { Diarrhoea, } \\
\text { abdominal pain }\end{array}$ & $\begin{array}{l}\text { Occasional } \\
\text { diarrhoea }\end{array}$ & $59-60$ & 43-46 \\
\hline 5 & M.M. & $\mathbf{F}$ & $\begin{array}{l}18 \\
24\end{array}$ & Yes & Diarrhoea & Nil & $59-61$ & $34-44$ \\
\hline 6 & K.C. & $\mathbf{F}$ & $\begin{array}{l}14 \\
20\end{array}$ & No & Nil & Nil & $58-61$ & $39-42$ \\
\hline 7 & D.McD. & $\mathbf{M}$ & $\begin{array}{l}20 \\
21\end{array}$ & No & Abdominal pains & Nil & $65-68$ & 63-68 \\
\hline 8 & F.G. & $\mathbf{F}$ & 14 & No & Nil & Nil & $58-60$ & $31-41$ \\
\hline 9 & M.R. & $\mathbf{F}$ & $\begin{array}{l}14 \\
21\end{array}$ & No & Leg pains & Nil & $58-59$ & $44-48$ \\
\hline 10 & S.McN. & $\mathbf{F}$ & $\begin{array}{l}15 \\
19\end{array}$ & No & $\begin{array}{l}\text { Diarrhoea, } \\
\text { abdominal pain }\end{array}$ & $\begin{array}{l}\text { Occasional } \\
\text { diarrhoea, } \\
\text { skin rash }\end{array}$ & $62-63$ & $44-45$ \\
\hline \multicolumn{4}{|c|}{$\begin{array}{l}50 \text { percentile for men } \\
50 \text { percentile for women at } 20 \text { years }\end{array}$} & $\begin{array}{l}69 \\
64\end{array}$ & $\begin{array}{l}65 \\
54\end{array}$ & & & \\
\hline
\end{tabular}

Table Clinical details of the teenage coeliac subjects

during the time of observation. Since the majority of subjects had passed the menarche the increase in height was small except in patient 2, F.T. All members remained below the 50 percentile for the normal population.

The increases in weight were of the same order in both groups, again with the exception of patient 2 . Once again all subjects remained below the $\mathbf{5 0}$ percentile.

\section{Jejunal histology}

The histology of the jejunal biopsies in each group is shown in figs $2 a, 2 b$, and $2 c$, both before and after the observation period. The initial specimen was 'flat', had an abnormal surface epithelium, and a heavy lymphoid infiltration in the lamina propria in all subjects.

In the gluten-free diet group, shown in fig 2a, the second specimens had normal (inset 6 and 9) or almost normal villi (inset 8 and 10). The biopsy in inset 7 was cut tangentially in error; however, the surface epithelium was normal suggesting that a normal pattern was present. The surface epithelium of the biopsies in the insets $6,8,9$, and 10 was also normal. The lymphoid infiltrate of the lamina propria was greatly reduced (normal) in the repeat biopsies.

In the other group (fig $2 b$ ) the change in villous pattern is minimal as between the two series of biopsies. The surface epithelium remained abnormal in all the repeat specimens, which included patient 7 , D.McD. (fig 2c) where minimal villous structures had developed (inset 7).

\section{ABSORPTION TESTS}

\section{D-xylose absorption test}

This gave a mean serum level for the group as a whole of $29.5( \pm 11.9 \mathrm{SD})$ and $38.2( \pm 13.6 \mathrm{SD})$ $\mathrm{mg} \%$ before and after the observation period respectively. Although showing a tendency to improve the difference is not significant $(t=1.52,0.10>P>$ 0.05).

The values for both groups were $24 \cdot 8$ ( $\pm 11 \cdot 1 \mathrm{SD})$ and $34.2( \pm 10.4 \mathrm{SD})$ before and $39.8( \pm 3.9 \mathrm{SD})$ and $36.6( \pm 18.9 \mathrm{SD}) \mathrm{mg} \%$ after the observation period. Again the difference between the groups after treatment was not significant $(t=0.37, P>0.5)$.

\section{Faecal fat}

The faecal fat excretion showed a similar tendency for the group as a whole to improve when the two admissions were compared. The mean values were $10.20( \pm 11.1 \mathrm{SD})$ and $4.5( \pm 2.5 \mathrm{SD}) \mathrm{g} /$ day before and after the study period respectively. The decrease, however, was not significant $(t=1 \cdot 58,0 \cdot 10>P>$ 0.05).

Also when the values for the gluten-free and nongluten free diet groups were compared, 8.7 $( \pm 5 \cdot 3$ SD) and 11.7 ( $\pm 14.6 \mathrm{SD})$ before and $4.2( \pm 2.7 \mathrm{SD})$ and $4.8( \pm 2.2 \mathrm{SD}) \mathrm{g}$ /day after the observation period respectively there was no significant difference in the final results $(t=0.32, P>0.5)$.

THE BIOCHEMICAL AND HAEMATOLOGICAL PAR AMETERS

Measurement of total proteins, serum albumin 


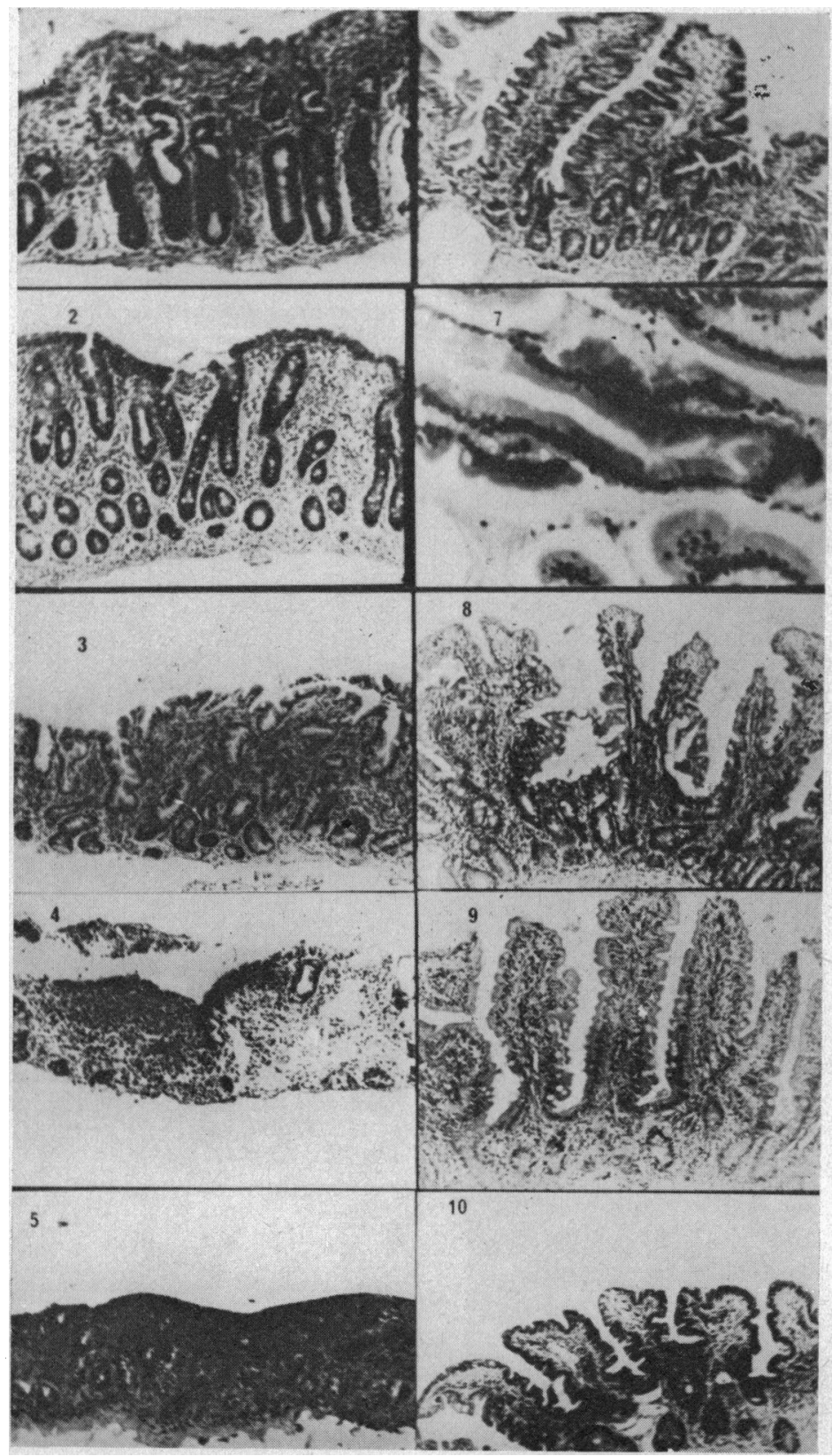

Fig 2a Gluten-free diet group: the first (left hand column 1-5) and second (right hand column 6-10) biopsies are placed so that specimens from the same patient are opposite each other. The return to a normal villous architecture is shown in 6 and 9, and to branching $(8)$ or stubby (10) villi in others. Normal surface epithelium is illustrated in 7. Pretreatment biopsies flat with heavy lymphoid infiltrates. $H \& E \times 62$ except 7 $(\times 250)$

calcium, phosphate, and vitamin $B_{12}$ showed no significant change when the patients as a whole were considered before and after the follow-up period or when the gluten-free diet group was compared with the non-gluten-free diet group. The haemoglobin $10.5( \pm 1.9 \mathrm{SD})$ before and $12.8( \pm 1.4 \mathrm{SD}) \mathrm{g} \%$ after the follow-up period $(P<0.0005)$ and mean corpuscular haemoglobin concentration $29.5( \pm 2.5$ D) before and 31.2 $( \pm 1.3 \mathrm{SD}) \%$ after observation $(P .<0.05)$ showed a significant increase and the alkaline phosphatase $20.6( \pm 10.3$ SD) before and $6.8( \pm 2.5$ SD) KA units after follow up (P $<0.002)$ showed a significant decrease. However there was no demonstrable difference between the gluten-free and 


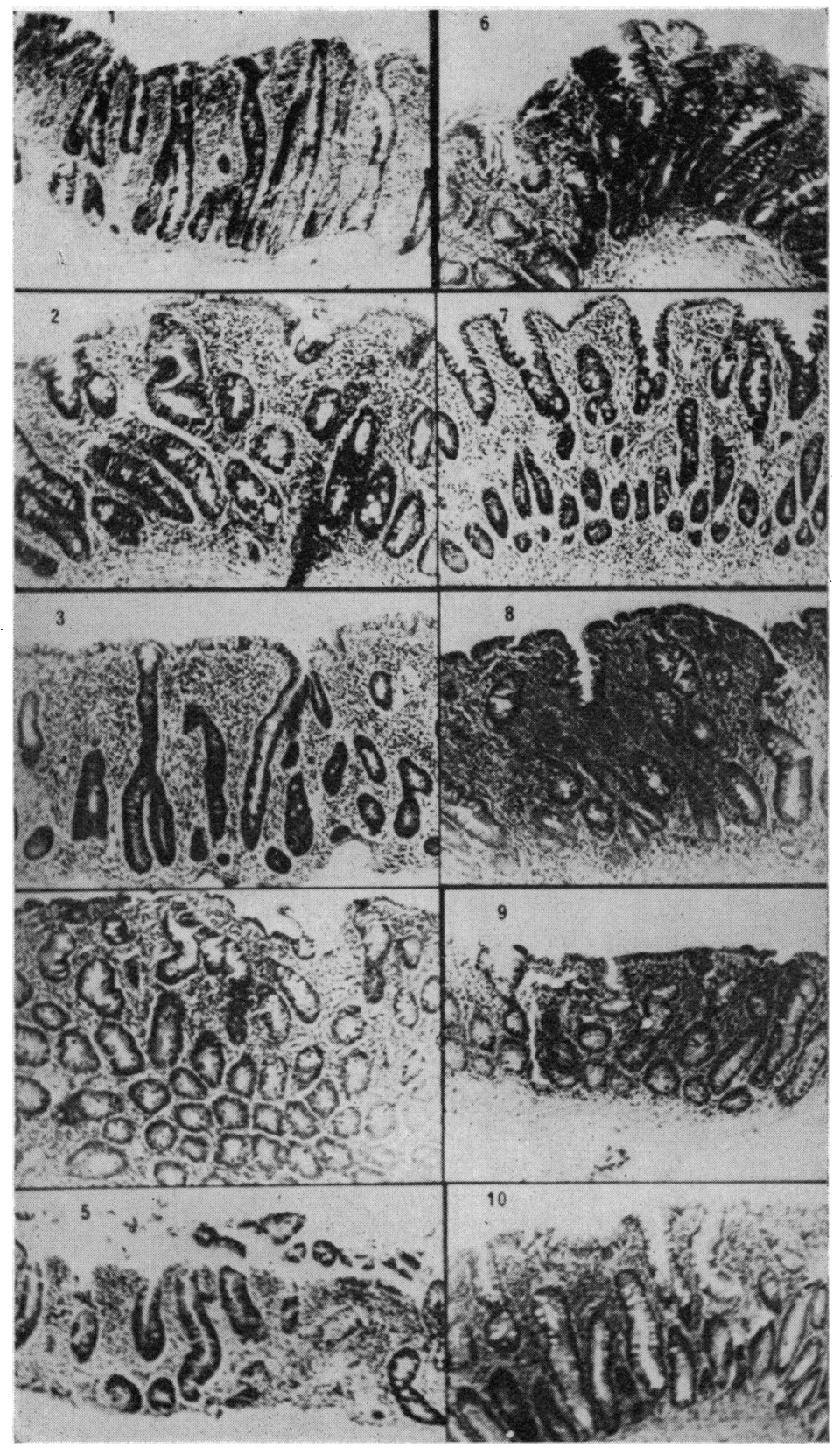

Fig. $2 \mathrm{~b}$ Non-gluten-free diet group: the first (left hand column 1-5) and second (right hand column 6-10) biopsies show little change. The second biopsies are almost flat with rudimentary villi in some (6 and 10); the stromal inflammatory infiltrate is unchanged and all show abnormal enterocytes. $H \& E \times 62$.

the non-gluten-free diet groups for any of these parameters.

The serum iron and folate levels showed no significant difference between the two groups at the beginning of the study. However, at the end of the follow-up period they were the only parameters which separated the two groups significantly. The serum iron values were $91.4( \pm 31.9 \mathrm{SD})$ and 43.2 $( \pm 15.9 \mathrm{SD}) \mathrm{mg} \%(\mathrm{P}<0.05)$ and the serum folate levels were $8.6( \pm 3.1 \mathrm{SD})$ and $2.0( \pm 1.1 \mathrm{SD}) \mathrm{ng} / \mathrm{ml}$ $(\mathbf{P}<0.02)$ for the gluten-free and the non-glutenfree diet groups respectively at the end of the study. When all the results are shown no significant pattern could be shown for the serum iron values, 


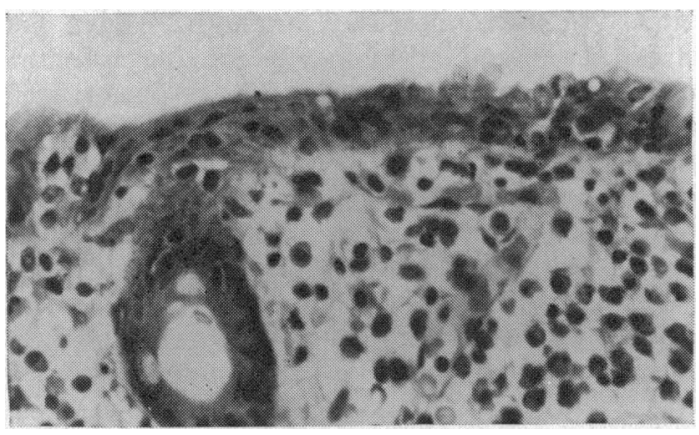

Fig 2c Non-gluten-free diet group: surface cells from inset 7 in previous figure. Lymphocyte infiltration is prominent and the enterocytes vary in height. $H \& E \times$ 250.

but the serum folate levels show a more consistently diverging pattern (fig 3). In particular it should be noted that the serum folate levels in patient 3 fell while she was off the gluten-free diet and rose during the latter stages of the study while she was on the diet (fig 1).

\section{Discussion}

It is now accepted that the fundamental criterion as to whether a patient is remaining on a strict glutenfree regime is the response of the intestinal mucosal histology (Pollock, Nagle, Jeejeebhoy, and Coghill, 1970). Thus the clear histological differences demonstrated between the gluten-free and nongluten-free diet groups on repeat biopsy in this study (figs $2 \mathrm{a}, \mathrm{b}$, and c) confirms the accuracy of the dietary history obtained in the group as a whole (fig 1). However, differentiation between the two groups on the basis of clinical signs and symptoms was almost impossible (see table) since patients in both groups went into symptomatic remission following their initial admission and remained so virtually throughout the observation period.

There was an overall clinical improvement in these patients which occurred regardless of their dietary regime. This was borne out by the improvement which was found in some of the laboratory assessments, namely, the rise in the haemoglobin and mean corpuscular haemoglobin concentration values and the fall in the alkaline phosphatase. Nevertheless these criteria did not discriminate between the gluten-free and the non-gluten-free diet groups. Other workers (Sheldon, 1969; Visakorpi, Kuitunen, and Savilahti, 1970; Hamilton and McNeill, 1972) have also found that once coeliac children have been started on a gluten-free regime, it is very difficult on the basis of clinical or laboratory criteria to dis-

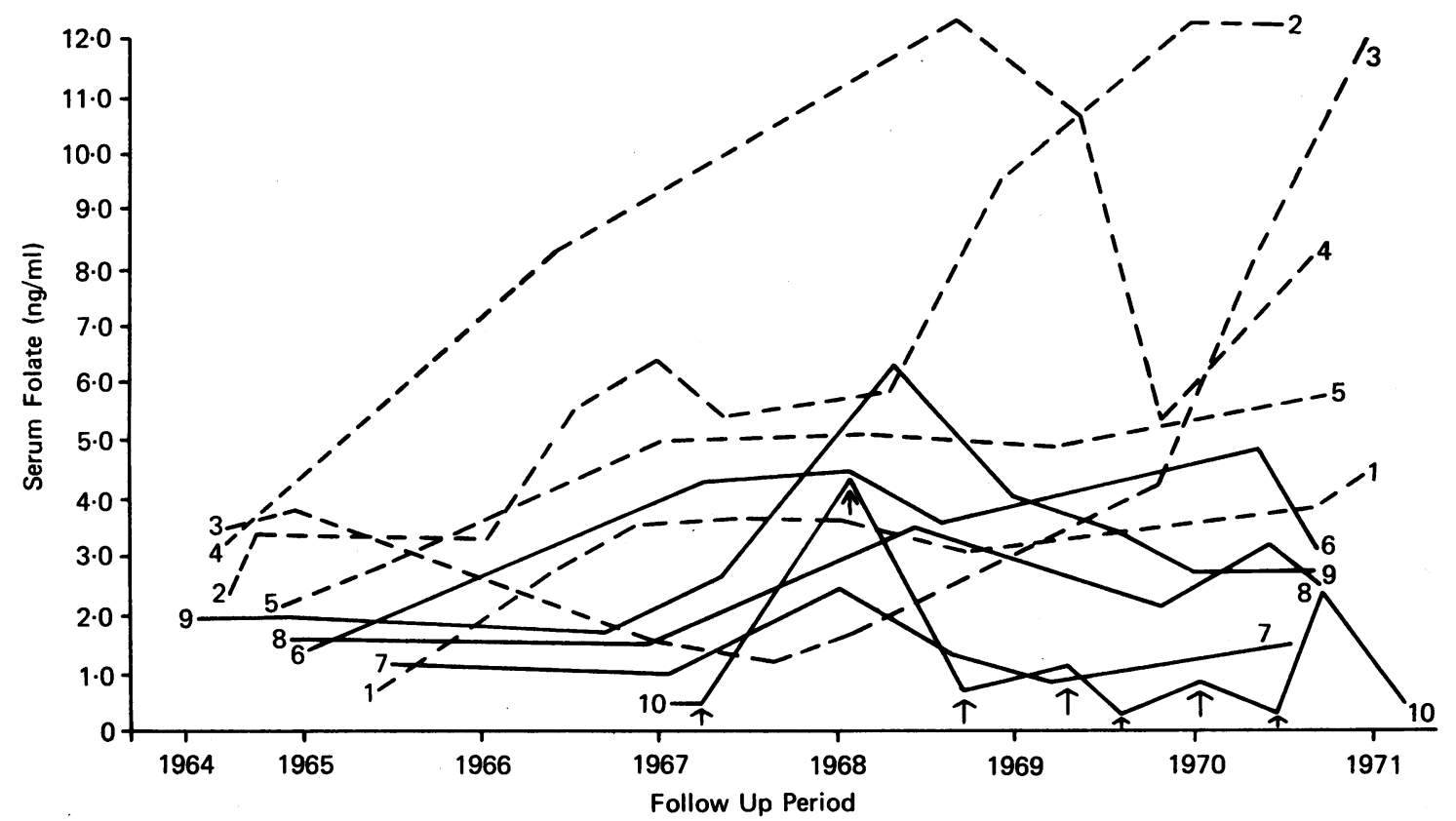

Fig 3 Serum folate values during period of investigation. (- - - gluten-free diet group; - _ non-glutenfree diet group; $\uparrow$ oral folic acid tablets prescribed.) 
tinguish between those who are and those who are not adhering to a strict gluten-free regime. This was especially true for faecal fat estimations.

It is perhaps surprising that the d-xylose absorption test, although confirming the overall improvement in these patients' condition, did not dissociate the two groups more accurately. Kendall, Nutter, and Hawkins (1972) have demonstrated that the d-xylose test can accurately demonstrate sensitivity to gluten in a susceptible person stabilized on a gluten-free diet. The technique employed to measure the d-xylose absorption in the latter study (Kendall, 1970) has important modifications from that used in this study and accordingly their method may be a more sensitive index of gluten toxicity.

The high serum alkaline phosphatase values obtained initially may be explained to some extent by the increased rate of bone growth which occurs at the menarche but also probably indicates a subclinical osteomalacia (Harris, Warner, and Cooke, 1969) which in turn indicates malabsorption of vitamin $D$. The significant fall in the phosphatase levels and the overall improvement in faecal fat excretion would suggest that the absorption of fat and fat-soluble vitamins did improve in these subjects regardless of the degree of 'flatness' of the intestinal mucosa or dietary regime. These findings suggest that the natural history of coeliac disease is for clinical remission to occur during early adult life regardless of dietary control. This remission, however, does not pertain to the jejunal mucosal histology.

The degree of malabsorption in coeliac disease is known to correlate better with the extent of the small intestinal mucosa involved than with the severity of changes in the jejunum (Hamilton, Lynch, and Reilly, 1969; Stewart, Pollock, Hoffbrand, Mollin, and Booth, 1967). It is possible therefore that although the jejunal mucosal histology remained abnormal in the non-gluten-free diet group that the extent of the small intestinal mucosal lesion diminished allowing an adequate amount of small intestinal function to produce the clinical remission.

In this study of the various biochemical and haematological indices performed the only ones which segregated those patients who were not persisting with a strict gluten-free diet were the serum iron and serum folate tests (fig 3). Although the serum iron values separated the two groups as a whole, the individual variation was such as to make it of limited practical value. The serum folate levels, on the other hand, apart from dividing the two groups, seemed to correlate reasonably closely with the variation in each individual's dietary regime.

It is well recognized that serum folate levels are reduced in coeliac disease (Dormandy, Waters, and Mollin, 1963) and indeed may be the sole presenting feature of the disease (Cooke, Fone, Cox, Meynell, and Gaddie, 1963). Hawkins (1971) has described the estimation as 'the single most useful screening test for coeliac disease'. Previous studies (Magnus, 1966; Mollin and Waters, 1968; Fry, McMinn, Cowan, and Hoffbrand, 1968) have also demonstrated that the serum folate level rises following treatment with a gluten-free diet. This study demonstrates the importance of serial serum folate levels as a measure of the clinical progress of the coeliac patient.

Since this study was started some authors (Hoffbrand, Newcombe, and Mollin, 1966; Magnus, 1966) have measured the red cell folate content rather than the serum level on the basis that the former will not be affected by day-to-day variations in the dietary folate intake. McNeish and Willoughby (1969) suggest that the whole blood folate may be a better screening test for coeliac disease in children. However, when a gluten-free diet is first instituted in coeliac patients the serum folate rises rapidly to a normal range, whereas the red cell folate shows a slower response (Chanarin, 1969). Not infrequently we have found that coeliac patients may present with a low serum folate and a normal red cell folate value. Thus the serum folate may mirror variations in the intestinal mucosa resulting from inadvertent gluten toxicity more quickly than the red cell folate. It would seem pertinent, however, that where possible both the serum and the red cell folate levels should be obtained on all occasions.

The aetiology of the folate deficiency which occurs in coeliac disease is probably a combination of malabsorption of food folate, increased loss of folate into the bowel, and reduced dietary intake (Weir, 1974). In the present study it may be significant that the group of patients who remained on a gluten-free diet started with serum folate levels which were higher than those of the non-gluten-free diet group. It may be that the former group remained on the gluten-free diet because they came from more enlightened and educated families than the latter. Accordingly the daily dietary intake of folate may also have been higher in the gluten-free diet group. It seems unlikely, however, that the divergent levels between the two groups demonstrated in this study are solely due to differences in dietary folate content as this would not explain the marked difference in jejunal mucosal morphology. While it is known that folic acid therapy may lead to improvement of the jejunal histology in tropical sprue (Swanson, Wheby, and Bayless, 1966), there is no evidence that similar changes occur in coeliac disease. 
We are indebted to Drs M. G Webb, M. Taylor, and D. McManus who at various times throughout this study helped to collect the relevant data. It is a pleasure to acknowledge our gratitude to Professor I. J. Temperley, in whose department the serum folate estimations were performed, and to Professor P. B. B. Gatenby, in whose department this study was started.

References

Austad, W. I., Cornes, J. S., Gough, K. R., McCarthy, C. F., and Read, A. E. (1967). Steatorrhea and malignant lymphoma: the relationship of malignant tumors of lymphoid tissue and celiac disease. Amer. J. dig. Dis., 12, 475-490.

Brunt, P. W., Sircus, W., and MacLean, N. (1969). Neoplasia and the coeliac syndrome in adults. Lancet, 1, 180-184.

Chanarin, I. (1969). The Megaloblastic Anaemias, p. 853. Blackwell, Oxford.

Chanarin, I., and Bennett, M. C. (1962). Absorption of folic acid and d-xylose as tests of small-intestinal function. Brit. med. $J$. 1, 985-989.

Cooke, W. T., Fone, D. J., Cox, E. V., Meynell, M. J., and Gaddie, R. (1963). Acute folic acid deficiency of unknown aetiology; temperate sprue. Gut, 4, 292-298.

Crosby, W. H., and Kugler, H. W. (1957). Intraluminal biopsy of the small intestine. Amer. J. dig. Dis., 2, 236-241.

Dormandy, K. M., Waters, A. H., and Mollin, D. L. (1963). Folic acid deficiency in coeliac disease. Lancet, 1, 632-635.

Fry, L., McMinn, R. M. H., Cowan, J. D., and Hoffbrand, A. V. (1968). Effect of a gluten-free diet on dermatological, intestinal, and haematological manifestations of dermatitis herpetiformis. Lancet, 1, 557-561.

Gough, K. R., Read, A. E., and Naish, J. M. (1962). Intestinal reticulosis as a complication of ideopathic steatorrhoea. Gut, 3, 232-239.

Hamilton, J. R., Lynch, M. J., and Reilly, B. J. (1969). Active coeliac disease in childhood. Quart. J. Med., 38, 135-158.

Hamilton, J. R., and McNeill, L. K. (1972). Childhood celiac disease: Response of treated patients to a small uniform daily dose of wheat gluten. J. Pediat., 81, 885-893.

Harris. O. D., Cooke, W. T., Thompson, H., and Waterhouse, J. A. H. (1966). Malignancy in adult coeliac disease and ideopathic steatorrhoea. Gut, 7, 710-711.

Harris, O. D., Cooke, W. T., Thompson, H., and Waterhouse, J. A. H
(1967). Malignancy in adult celiac disease and ideopathic steatorrhea. Amer. J. Med., 42, 899-912.

Harris, O. D., Warner, M., and Cooke, W. T. (1969). Serum alkaline phosphatase in adult coeliac disease. (Abstr.) Gut, 10, 951.

Hawkins, C. F. (1971). The investigation of malabsorption. J. clin. Path., 24, Suppl. (Roy. Coll. Path.), 5, 151-157.

Hoff brand, A. V., Newcombe, B. F. A., and Mollin, D. L. (1966). Method of assay of red cell folate activity and the value of the assay as a test for folate deficiency. J. clin. Path., 19, 17-28.

Kamer, J. H. van de, Huinick, H. ten B., and Weyers, H. A. (1949). Rapid method for the determination of fat in faeces. $J$. biol. Chem., 177, 347-355.

Kendall, M. J. (1970). The influence of age on the xylose absorption test. Gut, 11, 498-501.

Kendall, M. J., Nutter, S., and Hawkins, C. F. (1972). Testing gluten sensitivity by the xylose test. Lancet, 1, 667-668.

Magnus, E. M. (1966). Low serum and red cell folate activity in adult celiac disease. Amer. J. dig. Dis., 11, 314-319.

Mollin, D. L., and Waters, A. H. (1968). Nutritional megaloblastic anaemia. Symp. Swed. Nutr. Foundat., 6, 121-134.

Mortimer, P. E., Stewart, J. S., Norman, A. P., and Booth, C. C. (1968). Follow-up study of coeliac disease. Brit. med. J., 3, 7-9.

McNeish, A. S., and Willoughby, M. L. N. (1969). Whole blood folate as a screening test for coeliac disease in childhood. Lancet, 1, 442-443.

Pollock, D. J., Nagle, R. E., Jeejeebhoy, K. N., and Coghill, N. F. (1970). The effect of jejunal mucosa of withdrawing and adding dietary gluten in cases of ideopathic steatorrhoea. Gut, 11, $567-575$

Sheldon, W. (1969). Prognosis in early adult life of coeliac children treated with a gluten free diet. Brit. med. J., 2, 401-404.

Sheldon, W., and Tempany, E. (1966). Small intestine perioral biopsy in coeliac children. Gut, 7, 481-489.

Stewart, J. S., Pollock, D. J., Hoffbrand, A. V., Mollin, D. L., and Booth, C. C. (1967). A study of proximal and distal intestinal structure and absorptive function in ideopathic steatorrhoea. Quart. J. Med., 36, 425-444.

Swanson, V. L., Wheby, M. S., and Bayless, T. M. (1965). Morphologic effects of folic acid and vitamin $B_{12}$ on the jejunal lesion of tropical sprue. Amer. J. Path., 49, 167-191.

Temperley, I. J., and Collery, D. (1965). The significance of the serum vitamin $\mathbf{B}_{12}$ estimation in clinical practice. Irish J. med. Sci., 317-325.

Spray, G. H., and Temperley, I. J. (1966). Estimation of serum folic acid activity (Letter). J. clin. Path., 19, 410

Visakorpi, J. K., Kuitunen, P., and Savilahti, E. (1970). Frequency and nature of relapses in children suffering from the malabsorption syndrome with gluten intolerance. Acta paediat. scand., 59 , 481-486.

Weir, D. G. (1974). The pathogenesis of folic acid deficiency in man. Irish J. med. Sci., 143, 3-20. 